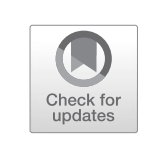

\title{
Understanding Nativist Populism
}

The recent surge of populist parties has brought back nationalism as a central element in European and American politics. However, understanding the phenomena can be a daunting task. Nationalism has many faces and its factions can be compartmentalized into many different categories. The relationship between nationalism and democracy has furthermore been precarious through history, and, thus, complex to analyse. Growing out of the Enlightenment and Romanticism, nationalism initially coincided with demands for democracy in the eighteenth century. In its most elementary form, it was the demand that nations had an inherent right to establish sovereign states, governed by the people.

Nationalism was thus a fundamental component of the struggle for democracy against absolutist monarchs in Europe, for example leading to the French Revolution. In that spirit, the heroic endeavours of the French national army during the Prussian invasion of 1792 were praised in their national freedom song, the Marseillaise. After the revolutions of 1848, nationalists saw democracy as part of the struggle for national independence. Nationalism is thus the ideology that synthesizes the social-cultural entity of the nation with the political entity of the state.

Nationalism spread rapidly through Europe and found its way into many of the European foreign colonies. In this regard, nationalism was the struggle against oppression, often forged in defiance of colonial powers. This was, for example, instrumental in Palestine, Lithuania, Cuba, Iraq and China. Nationalism also fuelled many separatist movements, such

(C) The Author(s) 2020

E. Bergmann, Neo-Nationalism, https://doi.org/10.1007/978-3-030-41773-4_2 
as in Catalonia and the Basque region in Spain, Quebec in Canada and the Scottish movement in the UK.

As I discussed in the Introduction to this book, the Westphalia peace agreement, signed in 1648 - ending the Thirty Years' War-gave birth to the international system of independent nation-states. For the most part of human history, people had, however, lived in other polities.

Nationalism has proven to be a resilient ideology and the nation-state, as a political entity, emerged as the underlying source for legitimacy of the global order. The nation-state is still the principal actor in international relations. Despite the internationalization of the political system, no other political order has emerged as a real alternative to the system of nationstates, which also has framed political identities in each of them. Identifying one's uniqueness is thus built into the very nature of nation-states, finding justification for its very existence by emphasizing what sets it apart from others.

As will become clear in the coming discussion, precisely this notion has proved to be a vital ingredient in the winning formula of contemporary nativist populist parties in Europe; they are staunchly nationalist. Before attempting to frame nativist populism more firmly, which I return to later in this chapter, I first take to discussing two underlying elements: nationalism and fascism.

\section{Nations and Nationalism}

Generally, nationalism departs from polarizing ideologies such as liberalism, anarchism, feminism, socialism and conservatism by its nature of encompassing the entire native population-this is a catch-all political approach. It can take on several forms and function across the political spectrum. Nationalism brings forth a feeling of belonging and discursively creates a common identity around the inner group. It emphasizes uniqueness and intra homogeneity, while often ignoring internal diversity. It sharpens the contrast between those who belong to the group and others who are alien to it. Benedict Anderson (1983) argues that this might explain why some people are willing to 'die for the nation'. And although nationalism was condemned in the wake of the Second World War, it has always survived. It is a feeling that often resides deep within people, not always completely consciously.

The rise of nationalism also brings the underlying concept of nation back into focus, which is even more challenging, and perhaps one of the 
most nuanced in social sciences. Indeed, scholars have for centuries been struggling to define what exactly constitutes a nation. A nation is closely linked to the idea of a heartland, a sort of a family that we belong to by birth.

In the late eighteenth century, the German philosopher Johann Gottfried von Herder (1784) maintained that a nation was in a way an extension of family. He wrote that nations were almost a natural phenomenon. He claimed that strong links existed between nature and nation; that traditions and habits in society emerged over a long period of time in a relationship between nature and the nation. Furthermore, he said the cultural essences of nations were kept in their languages. It was thus languages that really set nations apart. In this understanding, the nation survives the individual, and the mortal person lives on as part of the nation's history.

The French intellectual Ernest Renan (1882), disputed Herder's naturalist approach and claimed that nations were not natural, but rather culturally constructed. In his view, a nation was similar to a soul, a spiritual principle, some sort of a moral conscience-this is for instance the way that Vladimir Putin describes the Russian nation. Providing perhaps the only fully comprehensive definition to date, Renan said that distinguishable groups of people were a nation simply if they considered themselves to be one: 'a nation is a daily plebiscite', he claimed. This, however, is far too general to be useful.

In addition to Renan's definition, some identities and qualities can be listed which nations often share. Among these can be a separate land, shared history, common language, ethnic origin, religion and other cultural elements. One problem with these sorts of criteria listing definitions is that exceptions can always be found.

However, in this regard nations are perhaps not naturally, or only culturally, but also historically constructed. Nations rise, they can die out, and new ones can emerge. Most often, nations share a common understanding of their history, and unify around a myth of the past which continues to be reproduced.

Nations can be constructed in various ways. The German philosopher Friedrich Meinecke (1908), developed the concepts of Kultur-nation and Staats-nation to distinguish between the different sorts of nationalism in Germany and in France. On the one side there were nations like the Germans who build their nationhood on a common cultural heritage. On the other were nations like France, which more often were constructed by 
a common political history and based on a constitution. This could be simplified by saying that in Germany the nation had created the state, while in France the state had manufactured the nation.

\section{Discursive Constructs}

Contemporary scholars such as Ernest Gellner (1983) and Anthony Smith (2002) view nations as social creations and are, thus, in contrast to Herder's naturalist view. Still, Smith maintained that nations were much more firmly rooted than Renan claimed. According to Smith, nations-or ethnises more broadly - are 'named units of population with common ancestry myths and historical memories, elements of shared culture, some link to a historic territory and some measure of solidarity, at least among their elites'. Smith maintains that nations are logical and modern depictions of a deeply rooted common history and culture. He saw the nation as a 'sacred communion' of the citizens.

Benedict Anderson (1983) famously described nations as imagined communities. Gellner (1983) furthermore claimed that nations were created within the social relations of peoples of a similar culture. Nationalism, he claimed, was 'primarily a principle which held that the political and national unit should be congruent'. He saw the nation as superseding previous subgroupings, and thus being the most important social construction of contemporary time.

Eric Hobsbawm (1990) built on Gellner and claimed that nations were indeed creations of nationalism; without nationalism there were no nations. Similar to Renan, he considered 'any sufficiently large body of people whose members regard themselves as members of a "nation" to be such. He emphasized that even though nations were created from above, it was necessary to study nationalism from the view below, that is, 'in terms of the assumptions, hopes, needs, longing and interests of ordinary people', who were the objects of the nationalistic message.

For the purpose of this book, irrespective of whether Renan's, Smith's, Gellner's or indeed Hobsbawm's approaches are applied, nations can be seen as products of a common social understanding of those who belong to the national group. Similarly, Ruth Wodak (2015) views nations as perceptual constructs, arguing that they are 'mental communities', that people accept belonging to. Nations are also most often a social and cultural creation of a distinguishable group of people who unite around a common understanding of their shared history. 
Nationalism is thus in its essence a fictional invention, expressing an imagined will of a discursively created nation. As will become evident in the following three chapters, it is precisely into this social creation that contemporary nativist populists tap when constructing their discourse and framing their political message. In doing so they tend to exaggerate the distinctions between their own nation and others while overemphasizing internal homogeneity, often treating the nation as a single body.

\section{FASCISM}

Fascism emerges when political nationalism leads to authoritarianism, economic isolation and political extremism, based on viewing one's own nationality as above that of others. This sort of militant internal political nationalism can for instance be traced to the writings of Italian intellectual Giuseppe Mazzini (1862) in the mid-nineteenth century, who claimed that the highest level of freedom was not of individuals but the collective freedom of the nation. To reach higher freedom, he wrote, the individual surrenders his freedom over to the state. Since then, political nationalism has travelled different routes, most notoriously emerging into fascism in Italy in the 1920s, and Nazi Germany in the 1930s.

In practice, fascism was conceived from the crisis of liberalism in the wake of the First World War. Liberal democracy stood accused of having failed to bring about peace and prosperity. Max Ascoli and Arthur Feiler (1938) wrote that 'fascism was the product of democratic decay'. With democracy in disarray, both the political left and the right took to authoritarianism-communism on the left and fascism on the right.

Born in Italy, the word fascism derives from fascio, literally a bundle of rods strapped together forming an a stronger whole. Initially these were united bands of militarist nationalists declaring war on socialism. Travelling from the trenches of the war, fascism fused radical nationalism with the glorification of strength and violence as an answer to the crisis of liberal democracy. The interwar fascism, causing much of the pain Europe suffered in the twentieth century, was largely born out of the Great Depression of 1929.

Fascism was to a certain degree a dialectic response against the Enlightenment and early European liberalism that spread in the wake of the French Revolutions. Ernst Nolte (1966) for instance defined it as a simultaneous reaction against liberalism and Marxism. Fascists dismissed the era of political plurality that had existed prior to the outbreak of the 
Great War, denouncing democracy, freedom, tolerance and the liberal rights of the Enlightenment. Fascism was a counterattack against these principles of the French revolution, and instead found progress in consolidating authority into the hands of a strong leader who would unify the nation against its external enemies.

The fascist rhetorical platform did not rest on a coherent political philosophy. Rather, it rejected compromise and harboured contempt for established society and the intellectual elite. While emphasizing their own leaders' mystical relationship with the ordinary public, most of these movements were chauvinistic, anti-capitalist and advocated voluntary and violent actions against both socialist and bourgeois enemies.

Their anti-capitalist rhetoric was however, always very selective. Despite rhetorically siding with the working class, fascist regimes in government never did much to denounce capitalists, rather, they dissolved labour unions and banned strikes. Similarly, they criticized the bourgeoisie for lack of loyalty to the nation rather than for exploiting workers. In place of dismantling the capitalist order, in accordance with the argumentation, the interwar fascists offered instead a corporatist component to it, promoting the syndication of private capital and state within a dictatorial order.

\section{The (INFALLible) INTERPRETER}

Fascism always had a populist side to it. One of its central features is found in the claim that the leader is able to represent the people in a more thorough way than can be done in a representative liberal democracy. In fascism, the leader becomes the (infallible) interpreter of the true will of the people. He becomes the sacred source of the nation's desires. In many ways, fascism became a political religion with the leader positioned as prophet, who is worshipped by his followers.

Many of the contemporary populist movements do tap into similar mixtures of nationalism (rhetorical) anti-capitalism and an emphasis on voluntary actions against elites as fascists did in the interwar years. After the devastations of the Second World War, post-war far-right populists have, though, tended to camouflage their origins, dressing their politics differently, as I will discuss in the following chapters. Accordingly, the post-war nativist populists have largely moved away from this previous anti-democratic fascism. Most often they also refrain from openly referring to Mussolini's fascism or Hitler's Nazism. Still, as I discussed in the 
Introduction to this book, there are notable exemptions to that rulesuch as Jörg Haider referring positively to Adolf Hitler and Matteo Salvini to Mussolini.

In his book, Ur-Fascism, Italian writer Umberto Eco (1995), who was born in Mussolini's fascist Italy, warned that fascism could come back under the most innocent of guises. 'Our duty is to uncover it and to point our finger at any of its new instances-every day, in every part of the world.'

Robert Paxton (2004) similarly warned that this became an alibi for onlookers, and that fascism, was often overlooked in contemporary societies, most importantly in Western Europe, where he claimed fascists had always found the most fertile ground.

\section{Framing Populism}

Although not as notorious as fascism, populism is neither a neutral analytical concept. Unlike those who proudly identify themselves as socialists, conservatives, liberals, feminists, anarchists or even nationalists, people usually don't refer to themselves as being populists. Rather, populism is a pejorative label slapped onto other people's explanations that are perceived to be unfounded. It has commonly been used to belittle or marginalize rival explanations. The examiner must therfore be careful when applying it to his subjects.

The word populism stems from the Latin word populus, simply meaning the people. Correspondingly, the ancient population of Rome was referred to as Populus Romanus. The concept clearly corresponds to the NationVolk in German, Folk in Scandinavian languages. It relates to the public and stands directly in contrast to the elite.

Politics that relate first and foremost to the people have, of course, existed through the centuries. In itself, that is nothing new. Another key point is that populism as such does not contain either left or right leanings. Populist politics can tilt either way. Instead, at its core, the concept rather relates to the quest of bringing forth the pure will of the people. One of the first populist parties harnessing this essence was the American Peoples Party in the US in the 1890s, which sought to align farmers and workers and willingly described itself as populist.

In his influential book The Populist Zeitgeist, American-based Dutch scholar Cas Mudde (2004) describes populism as a 'thin-centred ideology' separating society into two homogenous and antagonistic groups: 'the pure people' versus 'the corrupt elite', emphasizing the 'general will' of 
the people. Mudde (2016) furthermore explains how 'the people' are then interpreted as a homogeneous moral entity.

According to this approach, the main aim of politics should be to realize the will of the people, rather than the elite being allowed to impose its will on the people. The domestic elite is here identified as a single actor. The elite is then accused of siding with international actors against the nation and the people. Here, the people are almost seen as sacred and being unassailable. As populism is a 'thin ideology', Mudde argues that it can be combined with a 'host ideology', such as nationalism, liberalism or socialism.

This is in line with what I discussed above; that populism exists in many different forms. As Margaret Canovan (1981) maintained, each trait is rooted in its own social and historical context. Populist politics is thus a broad church, and populism as such does not fit into one particular ideology. It is not a well-squared set of rational policies. Although scholars might differ on many aspects related to populist politics, most of them unite in recognizing their emphasis on the people versus the elite. As is the case with nationalists more broadly, any populist movement aims to mobilize the masses. Its appeal is to the people, rather than the elite. Indeed, like in nationalism as was discussed above, populist movements are catchall rather than class-based.

For populists, the people are always in a central position-a kind of heartland to be protected against both external threats and domestic traitors. As Ruth Wodak (2015) argues, populists endorse a nativist notion of belonging, presenting themselves as servants in the interests of the internal nation.

\section{ANTI-POLITICS}

A characterizing feature of populists is thus in positioning themselves as outsiders and casting their domestic opponents as an elite establishment. This was the position of the European fascists in the interwar years, as well as of the Latin American autocrats in the post-war years. And this has also been the position of contemporary populists in the West. The Le Pens, Farage, Wilders, Orbán, Trump and Salvini all positioned themselves as outsiders.

In comprehending the rise of populism, one has to understand the growing feeling among many people of being left behind in a fast-moving 
contemporary society, while others might be prospering. A sense of relative deprivation is thus key to understand the appeal of nativist populism.

Despite their different manifestations across time and regions, populist politicians unite in a Manichean worldview, in which societies are seen as divided between evil elites who are in control of the pure people. According to this binary viewpoint, the pure people are unaware of the malignant parasitic forces exploiting not only their naivety but also their inherited goodness. Populists generally split society into two, the people versus the elite/external others. The 'others' - whoever they are at any given time, domestic or foreign-are thus excluded from the demos. In this intolerant people vs anti-people binary, an exclusion of others is a vital component.

Although many other elements can be identified, the two central elements to populism are people-centrism and anti-elitism. This is the process of delegitimizing opponents and positioning them as enemies of the people. Alberto Fujimori of Peru linked his adversaries with drug trafficking and terrorism. Hugo Chávez of Venezuela equated his rivals with 'rancid pigs'. Silvio Berlusconi dismissed the judge's ruling against him in Italy as being communist. Like Rafael Correa of Ecuador, who called the media a 'grave political enemy', so did US President Donald Trump when branding the media as 'the enemy of the people'. Recep Tayyip Erdoğan in Turkey went even further when accusing journalists of propagating terrorism.

Politics is here cast as a dualistic struggle between the people and the undeserving and self-serving political class. As Daniele Albertazzi and Duncan McDonnel (2007) put it, populists 'pit a virtuous and homogenous people against a set of elites and dangerous "others" who are depicted as depriving the sovereign people of their property and rights'.

In their politics, populists thus tend to exploit a growing feeling among many in Western societies of being deprived and betrayed by the elite. In Kirk Hawkins' (2003) analysis, populists view politics as a struggle between good and evil, a discourse that counters 'the people' against the 'elite'. Ideologically, right-wing nativist populism is thus defined on the sociocultural dimension, rather than on the socio-economic axis.

As previously discussed, populists are prone to apply a rhetoric that undermines liberal democratic norms. This can be viewed as the practice of operating what can be branded anti-politics. Correspondingly, Andreas Schedler (1996) identified populism primarily with a broad array of antiattitudes: anti-elite, anti-establishment, anti-modern, anti-urban, antiindustrial, anti-state, anti-foreign, anti-intellectual and anti-minority 
sentiments. Taken collectively, populists are perhaps most simply 'naysayers' who resist change, as German scholar Hans Georg Betz (2001) claimed. In effect, they strive to stop modernization and social change.

\section{NATIVISM}

As already discussed, both nationalism and populism invoke 'the people', but they do so in different ways. The former traditionally encompasses the entire demos while the latter designates a narrower internal pure people against the corrupted elite. Recent years have seen the synergy of the two-or perhaps rather the entangling. In the following chapters I will document how populist movements have become increasingly ethnonationalist, and, indeed, nativist. American scholar John Higham (1955) defined nativism as an 'opposition to an internal minority on the grounds of its foreignness'. This is precisely the politics of contemporary nativist populists. Their nativism has mainly been sharpened in opposing the 'others' in society, primarily in protecting the native population against an influx of immigrants. Therefore, it is beneficial to identify the specifically nativist populism, the politics which separates outgroups from those who are considered as constituting 'the people'.

As discussed above, scholars have struggled with defining this phenomenon. Many have focused on the right-wing aspect of populism, mainly when dealing with extremist movements. Others have viewed them as primarily nationalist or even autocratic. Good arguments have been presented for each classification.

In previous books (see Bergmann 2017, 2018), I have applied the concept of nationalist populism. Roger Eatwell and Matthew Goodwin (2018) similarly use the term 'national populism', the ideology of prioritizing 'the culture and interest of the nation', while promising to 'give voice to people who feel that they have been neglected, even held in contempt, by distant and often corrupt elites'.

However, when dealing with political movements that have primarily found success in opposition to migrants and external influences, my focus here is on the nativist kind. In this book I maintain that the convergence of nativism and populism has turned into a separate Neo-Nationalism spreading across Europe and America. This has brought a new demand for reinforcing barriers between countries. In other words, this populist and nativist kind of contemporary nationalism, entangled with new kinds of communicative tools and tactics emerging in what has been branded 
'post-truth' politics, distinguishes modern-day nationalism from that of former times, which was discussed above. Therefore, the term NeoNationalism can be of benefit to understanding more broadly the phenomenon largely defining political developments.

This comeback of nationalism, now by way of nativist populism, can be seen as the return to the People ('Volk' /'Folk') that are in dire need of protection from an aggressive Other. As I will discuss in the following chapters this sort of identity narrative has been increasingly constructed in both European and American politics. Nativist populist movements reject the existing political consensus and combine anti-elitism with opposition against external threats. Vital for understanding the phenomena, the nativist othering can also be applied to the elite, which are also placed as an external (foreign in the understanding of Higham) threat to the people. As I will explore in the following three chapters, this rhetoric is then usually enhanced by crisis. This was the case in the post-Oil Crisis era, the post-1989 era, and in the wake of the Financial Crisis of 2008.

One element of the populist rhetoric is reducing complex problems and vast social developments down to simple solutions, such as the ousting of foreigners. Their infiltration into Our inherently good society is blamed for the present bad domestic situation, and also for the even bleaker future outlook. Thus, the solution is simple and clear cut: The cleansing of the external parasites.

Here, the process of 'othering' is vital to the populist rhetoric. The enemy must be clearly identifiable. For that, identifying stereotypes comes in handy. For instance: Jews are parasites; Muslims are infiltrating the West and staging a hostile takeover; Roma people are dirty; cultural Marxists are traitors; international institutions are undermining national authority; humanitarian organizations are preventing us from defending ourselves against these malicious elements.

\section{Cultural Separatism}

One aspect separating post-war nativist populism from interwar fascism is that biological racism was replaced with cultural xenophobia. In this transformation, arguments based on a racial hierarchy were replaced with an ethno-pluralist doctrine of 'equal but separate' (Rydgren 2005). Although humans were now considered biologically equal, culture still separated nations, which formed closed communities bounded by a common cultural identity. Claims for the superiority of Europeans and the Western 
world now thus relied on history rather than biology—often on an implicit but firmly underlying premise that Europeans were culturally superior.

Correspondingly, contemporary nativism, which here is under examination, does not necessarily revolve around race, but rather around culture. Well-integrated migrants with an established history in society can over time be considered a part of the native population. In other words, they become part of 'us' against 'other' external migrants. This is vital for understanding nativist populism. Importantly, the nativism of the NeoNationalists does not necessarily exclude descendants of immigrants that have been incorporated into the domestic demos.

Similar to biological racism, cultural racism constructs closed and bounded cultural groups and, as Karen Wren (2001) explains, 'conveniently legitimates the exclusion of "others" on the basis that they are culturally different'. As I will discuss later in this book, the French newright think tank Nouvelle-Droite developed this doctrine, based on a philosophical claim that nations had a right to cultural differences (McCulloch 2006). Swedish scholar Jens Rydgren (2007) points to how radical-right populists create an ethno-nationalist myth of the past, bringing their politics to revolve around reinstating the glory of their golden age.

Norwegian scholar Anders Jupskås (2015) furthermore claims that aggressive racist nationalism has been replaced by a defensive nationalism promoting a mono-cultural society within the borders of the nation-state. The new racist discourse thus relies on a nativist separation of 'us' who belong to the cultural entity, from 'others' who are not part of the nationhood and do not belong to it. In this identity-based political discourse, a myth around the history of the 'pure nation' is conversely created in order to legitimate the populist agenda.

The nation-state creation in Europe is within this discourse seen as a natural construction around cultural entities developing naturally. This proved to be a widely successful political framing. Cultural racism has found a foothold in Europe since the 1970s, specifically in opposing the cultural infiltration of 'others' who are deemed as not belonging to 'our' cultural entity.

The new-right discussed throughout this book surely taps into a nationalism of earlier periods but applies it in a less violent way; perhaps in what Michael Billig (1995) referred to as 'banal nationalism'- the everyday display of the nation in the public domain. Here, national pride and loyalty are reaffirmed in everyday routines in society. These can be monuments 
and other reminders of national heroes, the flying of flags, national holidays and celebrations, and so on.

Referring to Renan discussed earlier, this is the constant reproduction of the nation as a cohesive entity, which as a result begs protection. The counter-effect is the exclusion of 'others' such as immigrants, which perhaps was the very foundation of nativism in contemporary politics. In other words, nativist populists are culturally xenophobic.

\section{Simple Solutions}

As mentioned above, one of the main elements in populism is offering simple solutions to address complex problems. Whether it is Alexander Gauland in Germany, the Le Pens in France, Nigel Farage in the UK, Geert Wilders in the Netherlands or Donald Trump in the US, they all insist that solutions to the most pressing problems of ordinary people in society are much more straightforward than the establishment makes them out to be: If only immigration could be stopped, all would be better in France; exiting the European Union brings glory back to Britain; banning burqas and the Koran returns the cosy hippie ambience back to the streets of Amsterdam; only a grand and shiny border wall can keep Americans safe from Mexican immigrants.

As the populist message is based on offering straightforward solutions to often quite tortuous issues, they simultaneously accuse the mainstream authorities of distorting the will of the people, and of hiding their true agenda; as otherwise they would of course simply implement the easily applied solution.

Yascha Mounk (2018) identifies two types of accusations here. Either authorities are corrupt, or they are working on behalf of outside interests. The specifically nativist populists tend to focus on the latter, insisting that the domestic authority is not loyal to the people, but is in bed with foreign aggressors. This then crystallizes the populist message: With ousting the elite from power and implementing the simple solution Britain/France/ Russia/America/will become great again.

After coming into power, populists have often found themselves in trouble when they cannot implement the simple remedy to the malignant condition. Think of Brexit or stopping immigration to America. A similar tactic is then often applied against domestic institutions, that are not under control of the populist authority. They are blamed for preventing the leader from implementing the will of the people and accused of betrayal, 
be they the state-run media not toeing the populist line, independent courts, elections councils, ethical watchdogs or the military refusing to implement illiberal orders. Think for example of Boris Johnson and the British Parliament and Supreme Court attempting to stop Brexit, or of Donald Trump and the Deep State apparatus in Washington. In these sorts of situations, all sorts of conspiracy theories become a useful tool in shifting the viewpoint and agenda.

The next step for the authoritarian populists is bypassing disobedient public institutions, sometimes through rewriting the constitution and consolidating power in the hands of the leader, such as in Venezuela, Hungary and indeed in Russia. In America Donald Trump promoted a national emergency to bypass Congress in order to build his border wall.

\section{STYLE AND CONTENT}

Populism can furthermore be seen as a style, or a technique, of political mobilization and communication. The main method is in constructing fear among the public and in pointing to scapegoats that are blamed for ruining - or threatening to ruin-our (inherently good) society. However, as for instance Ruth Wodak (2015) argues, radical-right populism is not only a form of rhetoric. Rather, it also contains specific and identifiable contents. Both style and substance are thus interlinked in populist politics.

As will become evident over the following three chapters, the fear that they instate is, for instance, of a specific and identifiable kind. It consists of several core aspects, such as losing jobs to immigrants, and of migrants undermining the welfare state to the detriment of the vulnerable and the elderly among the native population. Furthermore, the rhetoric usually points to the increasing powerlessness of the nation-state in protecting the intranational public. It warns against the erosion of values and the demise of traditions and native culture.

These are actually some of the main forms of the populist appeal, and, as I mentioned in the Introduction to this book, it would be mistaken to dismiss all these concerns as unfounded. In fact, they might easily have some merit. Still, the way these concerns are articulated is often quite populistic.

One communicational aspect comes with the use of all kinds of rhetorical fallacies. Of course, rhetorical fallacies have been used in political debates throughout the centuries, when politicians attempt to mislead the discussion for their own gain. Studies have found that populists have been 
more prone than mainstream politicians to apply informal fallacies in their rhetoric (Blassnig et al. 2019).

These can be of several kinds. They might include ad hominem arguments such as personal attacks rather than tackling arguments put forth by opponents. Donald Trump for example added negative nicknames to his opponents, such as 'Crooked' Hillary, 'Little' Marco and 'Lying' Ted. False cause is another version, when wrongly attempting to create causal links between separate acts. Faulty analogy is when comparing things that are only partly compatible. A straw man is created when misrepresenting the argument of one's opponent. A red herring is the deviation from the topic at hand by pointing to something else that might only be loosely related to the issue.

As will come to light in the following chapters, these and many other rhetorical fallacies are often used to derail the discussion and steer it into directions that better serve the interests of the operator.

\section{Four-Step Rhetorical Formulation}

One aspect of the populist rhetorical style entails dramatization-being deliberately provocative in order to draw attention and promote polarization. This can be done by breaking publicly accepted norms such as in dismissing an entire religion as a 'dangerous totalitarian ideology', as Geert Wilders of the Netherlands did when denouncing Islam. ${ }^{1}$ This process of eroding norms generates tension for the purpose of rallying support for the party-in opposing the 'other' or/and the 'establishment'.

Central to their appeal is how they put the spanner in the works of the establishment. This can be understood as the politics of disruption, protesting against scripted political performance. Lone Sorensen (2018) documents how populists instead tend to claim authenticity by exposing the professionally calculated and scripted performance of the elite. The normbreaking provocations of populist actors thus contradicts the mainstream, and, in doing so projects some kind of authenticity. It also generally triggers protest from the mainstream. In turn, the populists are then able to exploit that response by complaining of ill treatment by the 'politically correct' mainstream - an interlinked established authority in politics, academia and media. In the new landscape of digital media this kind of communication now spreads much further than before and allows the populist actor to weaponize with visibility. This dynamic can be structured into a 
four-step rhetorical formulation, by in which populists come to dominate the political agenda (Wodak 2015).

First comes the scandalous act or comment of the populist, for instance a racist comment against a Muslim. That triggers a push-back from mainstream actors opposing the racist comment. The third step is then for the populist to claim victimhood and/or deflecting by pointing to others, even equating the comment in question with something entirely different. The final step is going on the offensive and dramatizing the cycle with exaggerations, emphasizing the right to free speech and accusing those that countered the initial comment of silencing and oppression. As can be seen in the following three chapters, it is through this rhetorical pattern that populists have been able to set the agenda.

The ever hungry 24-hour rolling news media and the modern online media are widely exploited for transmitting the scandalous message of the populists. In fact, the new media became an instant bedfellow with populism, as both benefitted from one other. The new media provided the populists with the oxygen of attention that they desperately needed to succeed. Because of audience interest, the media in fact became obsessed with the norm-breaking behaviour of many populists. In the new media environment, sensational stories travel much faster and further than the more serious and traditional news. In fact, as I will return to discussing in a later chapter, fake news is shared far more often on social media than mainstream news.

\section{The Führer Principle}

As was the case with fascism, populist movements have usually only found success when led by charismatic leaders. They are more leader-driven than based on a clear party structure. One of their main forms of appeal is in positioning their leader as the saviour of the ordinary people. In the case of the nativist populist, this comes more specifically in the form of saving the people from an external threat and the traitorous elite.

Democracy is here usually viewed very narrowly, often simply intertwined with the will of the leader, who-as I discussed above-becomes the interpreter of the people. Not only is a fictional single desire attributed to the entire demos, but the leader is also seen to understand the true will of the people even more clearly than the public might do themselves. As Frederico Finchelstein (2017) writes, 'populism replaces representation with the transfer of authority to the leader'. 
Many examples of this can be mentioned. In 2017, Marine Le Pen ran her presidential campaign on the slogan 'Au nom du peuple', meaning in the name of the people. In 1988 her father Jean-Marie Le Pen had run on a slogan 'Le Pen, le peuple', meaning Le Pen, the people. Donald Trump toed a similar line when claiming before the 2016 presidential election: 'I am your voice.' Pegida in Germany insisted 'Wir sind das Volk', meaning we are the people. Perhaps this idea is not in a completely separate category from the claims made by Louis XIV, the absolutist king of France, who in the late eighteenth century famously-and ever so arrogantlyinsisted that he, personally, was the state: 'L'Etat, c'est moi'.

Many similarities can also be drawn between populist politics and celebrity culture. The populist leader often approaches the public in a way similar to pop stars, applying the same frontstage techniques in drawing attention, for instance, appearing in tabloids rather than in the mainstream well-regarded and sophisticated broadsheet media outlets. Perhaps this is similar to the way pop culture challenged the fine arts in the latter half of the twentieth century-in effect obfuscating much of the so-called (and sometimes imagined) high society. Akin to rock stars, the populist leader rather appeals to the public, than to sophisticated high society.

\section{INTOLERANT DEMOCRACY}

What sets contemporary right-wing nativist populists apart from earlier fascist and Nazi versions-discussed above-who favoured authoritarian leadership, is that most of them now accept democracy and parliamentarianism, at least in name. They are thus more anti-elite than anti-system.

However, although contemporary nativist populism clearly parts from pre-war fascism, mainly in rejecting political violence and accepting enforcing the democratic will of the people, it still taps into the same ideological source; in both instances for example, always attributing a single (invented) will to the demos. This collectivist approach clearly contradicts the pluralist values of liberal democracy.

In fascism, Umberto Eco (1995) wrote, individuals have no rights. Instead, 'the People is conceived as a quality, a monolithic entity expressing the Common Will'. Eco said that 'The People is only a theatrical fiction', and since large groups of people don't usually share a common will, the leader becomes their interpreter. This same fascist element has filtered over to contemporary nativist populism. 'We no longer need the Piazza Venezia in Rome or the Nuremberg Stadium', Eco wrote. 'There is in our 
future a TV or Internet populism, in which the emotional response of a selected group of citizens can be presented and accepted as the Voice of the People.'

This homogenizing element of a cohesive people promotes intolerance within democracy. It is an illiberal form of democracy, rejecting diversity and stripping away its inhered emphasis on individual rights and the separation of power. This is democracy without liberal rights. Therefore, it might be mistaken to think of modern populism as void of authoritarian tendencies.

However, populists do depart from neo-fascists and neo-Nazis when aiming to reshape and redefine democracy, rather than dismissing it altogether. As discussed, the relationship between populism and democracy is both murky and ambivalent; democracy is diminished to being understood as the majoritarian will as interpreted by the leader.

\section{A Winning Formula}

In the late 1990s Herbert Kitschelt (1997) introduced what he called the 'winning formula' of right-wing populism, in combining neo-liberal politics with authoritarianism and a policy of anti-immigration. In addition to Kitschelt's formula, another aspect for the success of nativist populists is also found in the way that they are able to combine a powerful message of imminent external threat with an aggressive style of communication, speaking on behalf of the ordinary man against the corrupt elite.

I thus maintain that the winning formula is furthermore and also found in the dual processes of instating fear and scapegoating. First fear is created and then blame is attributed. Fear is used to legitimize policies of protecting the people, of putting up barriers, closing borders, ousting immigrants, exiting international institution, emasculating the elite, and so on.

Not only are these policies justified by the emanating threat, but it indeed becomes the duty of authorities, the populists argue, to protect the ordinary public by instating them.

\section{Three Waves}

Similar to fascism in the interwar years, which was at least partly born out of the Great Depression of 1929, the post-war nativist populist movements have also tended to surge in the wake of crises. In the late 1980s, professor of politics Klaus von Beyme (1988), identified three waves of 
extreme-right politics since 1945: First the nostalgic wave of fascism that arose in Germany and Italy before soon dying out; secondly, the anti-tax wave in the 1950s and 1960s, mostly found in France; and finally a more pan-European trend appearing in the 1980s.

Benjamin Moffitt (2016) also separated different forms of populism over time, between early and new populism. The earlier version included the Latin American movements lasting from the 1930s to the 1960s, and the McCarthyism of the 1950s. The latter kind of populism, Moffitt maintains, started in the late 1980s and early 1990s and included for instance Jean-Marie Le Pen of France, Jörg Haider of Austria and Umberto Bossi of Italy.

For understanding specifically nativist populism in the post-war era up until 2020, which is my intention in this book, a different categorization of three main waves of populism is here more useful. As was mentioned above, the first arose in the wake of the Oil Crisis in the 1970s. The second wave grew out of resentment in Western Europe against workers from the Eastern part of the continent flocking over the former Iron Curtain after the collapse of the Berlin Wall in 1989. A sudden spike within this wave occurred in the wake of the terrorist attacks in the US on 11 September 2001. Finally, the third wave was brewing in the wake of the international financial crisis starting in 2008, reaching new heights on the canopy of the 2015 refugee crisis.

As will become evident when analysing these waves in the following chapters, each is identified by their own qualities. The first wave rose rather on an anti-tax and a neo-liberal notion, instead of being based on hardcore nationalism. At first sight this might seem a bit paradoxical, as initially most populists of the first wave were positioned much further out on the fringe in politics than those finding support in the third wave. However, although many of them resorted to rogue demagoguery, their aim was initially mainly against big government and the corrupt domestic political elite. Nationalistic sentiments rose more clearly to the surface during the second wave, when populist parties were refocused and opposed multiculturalism and immigration. In the third wave, nativist populists became much more mainstream and were by that time firmly centred against mainly Muslim immigration. During the Coronavirus Crisis of 2020 nativist populists around the world reverted to renewed nationalist responses, elevating the likelihood of another rise of Neo-Nationalism, which I will discuss later in the book. 
In the following chapters I will further trace this progression of populist parties across the different parts of the European continent as well as in America. Despite the varying evolutions across regions and time, and their varied aspects-all examined further in the following chapters-most of these parties have been quite distinct from the interwar fascist versions. As I mentioned above, these newer waves of nativist populism depart from earlier fascist movements in that contemporary nativist populists do not denounce democracy. Rather, their sights are set against the liberal aspects of the post-war Western democratic order. Secondly, and equally important, is that biological racism was replaced with cultural racism. For this reason, I maintain that post-war nationalism should be understood as a novel populist version, that is, as Neo-Nationalism.

\section{Common Qualities}

Whichever viewpoint we choose from the differing definitions discussed above, some similarities can still be identified, which might help in framing the phenomena. Here, however, the focus is firmly on those that can be understood as specifically nativist populist. Despite their variations, nativist populist parties have many qualities in common, as will be explored.

In my previous research analysing nationalism in the Nordic countries (2017), and far-right conspiracy theories in Europe (2018), I have developed a scheme identifying ten common qualities of nativist populism. In the following chapters I will build on that framework in mapping the progression of populist movements in Europe and across the Atlantic over the three waves here identified.

First of all, the populists here analysed are nationalist and nativist. Within a nostalgic framework, they are prone to apply myths in order to bring people together within common and cohesive national boundaries.

Secondly, they are exclusionary. They create a division between 'us' who belong to society and 'them' who should not belong to it. Who they are can be, for example, immigrants, asylum-seekers, ethnic or religious minorities, even the domestic political elite. The others are discursively turned into enemies of us, threatening our identity and culture or exploiting and ruining the welfare state 'we' have built. Others are here clearly distinguished from the ethnic natives, $u s$. This often results in open xenophobia and racism. In Western Europe, this is most often aimed against 
Muslims, for example, in Austria, Denmark, France and the Netherlands, while in Eastern Europe the targets are often Roma people or even Jews, as was the case in earlier times. Perhaps most obviously, they campaign against multiculturalism and strive to stem the flow of immigration.

Thirdly, populist movements often revolve around a strong charismatic leader. Most often they rely on what they claim to be a special relationship between the leader and the ordinary public. Particularly, the leader is often seen to understand the burdens of the ordinary public, which, vitally for the story, is being overlooked by the established political elite. The populist leader, on the other hand, usually claims to know how to solve the people's problems. As result, the leader becomes the interpreter of the will of the people.

This brings forward the fourth shared characteristic. Populists are antiintellectual and anti-elitist. This is often the case even though their leaders themselves often tend to come from the same privileged background as the elite they are fighting against. Still, they claim to be advocates of the nation, and seek to speak in its name. In doing so they differentiate between honest ordinary people and the corrupt elite and discursively turn them into two homogeneous and antagonistic groups. One of their main successes recently has been in criticizing the consensus politics of the corrupt political elite.

Five, the message for solving the ordinary public's most pressing problems tend to be simple; these are straightforward solutions to meet complex national interests. Often they call for mobilizing answers, such as the cleansing of foreign parasites.

Six, populism is more moralistic than practical. They tend to speak to emotions rather than to reason and to avoid intellectual debate. Populists are often not bothered by contradictions, for example, simultaneously promoting economic liberalism and the lowering of taxes, while also promising increased welfare services and easy implementation of high cost policies.

Seven, while often claiming to be economically liberal, populists are more usually protectionist of national production from international competition, especially in the field of agriculture. Often, they exploit a lack of confidence, for example in the wake of a crisis. They voice the dissatisfaction of those losing out to increased globalization and rapid social change.

Eight, populist parties are usually authoritarian and social conservatives; they believe in a strictly ordered society and are rather defined on socio-cultural aspects than on the socio-economic scale. Nativist populists 
are thus not necessary positioned on the classical economic right. They emphasize family values and law and order, often claiming that the system protects criminals rather than their victims among the ordinary public. Another aspect here is that they disproportionally bring attention to crimes conducted by alien forces, such as migrants.

Ninth, their understanding of democracy is illiberal. They claim to be able to interpret the will of the people. Correspondingly, they have contempt for traditional gatekeepers, such as specialists and mainstream media. Instead they attempt to appeal directly to the people, through their own media, social media and public events, rallies-and so on.

Finally, in international relations populists are usually suspicious of multilateral institutions. In Europe they are most often staunchly Eurosceptic. Some only talk about stemming further integration, while others strive to push back Europeanization and even abolish the European Union.

\section{A Threefold Claim for the People}

Taken collectively, nativist populists put forth a threefold claim in their support of the people:

- First, they tend discursively to create an external threat to the nation.

- Second, they accuse the domestic elite of betraying the people, often even of siding with the external aggressors.

- Third, they position themselves as the true defenders of the 'pure people' they vow to protect, against both the elite and these malignant outsiders, that is, against those that they themselves have discursively created.

In the following three chapters I will apply this model when analysing the political discourse of contemporary nativist populists-the $\mathrm{Neo}^{-}$ Nationalists of our time.

\section{Note}

1. Breitbart.com. 2017, 28 February. 'Geert Wilders: Islam Is Not a Religion, It's a Totalitarian Ideology'. 


\section{REFERENCES}

Albertazzi, D., \& McDonnell, D. (2007). Twenty-First Century Populism: The Spectre of Western European Democracy. London: Palgrave Macmillan.

Anderson, B. (1983). Imagined Communities: Reflections on the Origin and Spread of Nationalism (Rev. ed.). London and New York: Verso.

Ascoli, M., \& Feiler, A. (1938). Fascism for Whom? (1st Unknown ed.). W. W. Norton \& Company.

Bergmann, E. (2017). Nordic Nationalism and Right-Wing Populist Politics: Imperial Relationships and National Sentiments. London and New York: Palgrave Macmillan.

Bergmann, E. (2018). Conspiracy \& Populism: The Politics of Misinformation. London: Palgrave Macmillan.

Betz, H. G. (2001). Exclusionary Populism in Austria, Italy and Switzerland. International Journal, 53(3), 393-420.

von Beyme, K. (1988). Right-Wing Extremism in Western Europe. London and New York: Routledge.

Billig, M. (1995). Banal Nationalism. London: Sage.

Blassnig, S., Büchel, F., Ernst, N., \& Engesser, S. (2019). Populism and Informal Fallacies: An Analysis of Right-Wing Populist Rhetoric in Election Campaigns. Argumentation, 33(1), 107-136.

Canovan, M. (1981). Populism. San Diego: Harcourt.

Eatwell, R., \& Goodwin, M. (2018). National Populism: The Revolt Against Liberal Democracy. Penguin UK.

Eco, U. (1995, June 22). Ur-Fascism. The New York Review of Books.

Finchelstein, F. (2017). From Fascism to Populism in History. University of California Press.

Gellner, E. (1983). Nations and Nationalism. Ithaca: Cornell University Press.

Hawkins, K. (2003). Populism in Venezuela: The Rise of Chavismo. Third World Quarterly, 24(6), 1137-1160.

von Herder, J. G. (1784). Ideen zur Philosophie der Geschiche der Menschheit.

Higham, J. (1955). Strangers in the Land: Patterns of American Nativism, 1860-1925 (Rev. ed.). New Brunswick, NJ: Rutgers University Press.

Hobsbawm, E. (1990). Nations and Nationalism since 1780: Programme, Myth, Reality. Cambridge: Cambridge University Press.

Jupskås, A. R. (2015). The Persistence of Populism. The Norwegian Progress Party 1973-2009. Oslo: University of Oslo.

Kitschelt, H. (1997). The Radical Right in Western Europe: A Comparative Analysis. University of Michigan Press.

Mazzini, G. (1862). The Duties of Man. Chapman \& Hall.

McCulloch, T. (2006). The Nouvelle Droite in the 1980s and 1990s: Ideology and Entryism, the Relationship with the Front National. French Politics, $4(2), 158-178$. 
Meinecke, F. (1908). Cosmopolitanism and the National State. Princeton: Princeton University Press.

Moffitt, B. (2016). The Global Rise of Populism: Performance, Political Style, and Representation. Stanford University Press.

Mounk, Y. (2018). The People Vs. Democracy: Why Our Freedom is in Danger and how to Save it. Harvard University Press.

Mudde, C. (2004). The Populist Zeitgeist. Government and Opposition, $39(4), 541-563$.

Mudde, C. (2016). On Extremism and Democracy in Europe (Vol. 34). Routledge.

Nolte, E. (1966). Three Faces of Fascism: Action Francaise, Italian Fascism, National Socialism (1st ed.). Henry Holt \& Company, Inc.

Paxton, R. (2004). The Anatomy of Fascism. London: Penguin Books.

Renan, E. (1882). Qu'est-ce qu'une nation? Presented at the Paris: Sorbonne. Paris: Sorbonne.

Rydgren, J. (2005). Is Extreme Right-Wing Populism Contagious? Explaining the Emergence of a New Party Family. European Journal of Political Research, $44(3), 413-437$.

Rydgren, J. (2007). The Sociology of the Radical Right. Annual Review of Sociology, 33, 241-262.

Schedler, A. (1996). Anti-Political-Establishment Parties. Party Politics, 2(3), 291-312.

Smith, A. D. (2002). Nations and Nationalism in the Global Era. Cambridge: Polity Press.

Sorensen, L. (2018). Populist Communication in the New Media Environment: A Cross-Regional Comparative Perspective. Palgrave Communications, $4(1), 1-12$.

Wodak, R. (2015). The Politics of Fear: What Right-Wing Populist Discourses Mean. New York: Sage.

Wren, K. (2001). Cultural Racism: Something Rotten in the State of Denmark? Social and Cultural Geography 2(2), 141-162. 